\title{
Self-Defense: What's a Jury Got to Do with It?
}

\author{
Jean K. Gilles Phillips \& Elizabeth Cateforis ${ }^{*}$
}

\section{INTRODUCTION}

A dead body lies in the parking lot of a bar, and a knife lies by the body's right hand. The window of a car is shattered. A man stands nearby with a gun in his hand. There are fifteen to twenty people in the parking lot, and many more inside the busy bar. Police, on routine patrol, arrive almost immediately.

The police secure the scene, not allowing anyone to leave. When more officers arrive, they begin interviewing the people in the parking lot, including the shooter. Other officers question patrons inside the bar.

The shooter tells the officers that he and the dead man were strangers and that they had gotten into a fender bender in the parking lot. After the shooter got out of his car, the decedent got out of his car too. Egged on by passengers, the decedent started yelling obscenities, and then, with a knife in his hand, charged the shooter. The shooter pulled the gun he was carrying and shot twice, hitting both the decedent and the occupied car. The shooter stated that he was in fear for his life, as the decedent charged at him "like an angered bull." The shooter's girlfriend, who was in the car with him, and several of the shooter's friends who were on their way to their cars, corroborate this version of events. In addition, several others saw the decedent with a knife running at the shooter, but only otherwise heard lots of yelling and gunshots.

The passengers in the decedent's car offer a different version of the event. They agree that the fender bender was an accident. According to each of them, the shooter got out of his car with his gun drawn, cursing about the decedent's "drunk ass" driving, making threatening gestures with the gun. The decedent got out with a knife, but only as protectionhe was trying to diffuse the situation. The people in the car believe that the shooter purposefully shot into the car-it was then that the decedent rushed the shooter and was shot.

Jean Phillips and Elizabeth Cateforis are Associate Clinical Professors in the Paul E. Wilson Defender Project at the University of Kansas School of Law. 
The levels of intoxication varied tremendously from witness to witness, including the car's occupants. People still inside the bar remember the two men having a verbal exchange that threatened to get violent and that the men's friends were involved. The bartender tells the police that he ultimately threw a bunch of them out.

Following the investigation of the case, law enforcement forwards reports to the prosecutor, suggesting charges be filed against the shooter. The prosecutor reviews all the information and decides that the shooter should be charged with felony murder, ${ }^{1}$ and the underlying felony of criminal discharge of a firearm into an occupied vehicle. ${ }^{2}$

The shooter decides to proceed to trial on the charges, planning to assert self-defense in justification for his action. When he requests to introduce evidence of self-defense, the State objects, citing a relatively new Kansas case, State v. Kirkpatrick. ${ }^{3}$ The defendant objects on due process grounds. The court sustains the State's objections and the shooter is convicted. On appeal, the defendant raises issues relating to the exclusion of the self-defense evidence.

Is the trial court's exclusion of self-defense evidence sustainable? This Article explores the answer to this question from several angles. It begins with a detailed discussion of Kirkpatrick and a relatively new Kansas statute, K.S.A. $21-3219,{ }^{4}$ to explain the current relationship of self-defense and a forcible felony charge. Subsequently, the historical roots of self-defense are discussed and used to demonstrate that the determination of self-defense, as a fact-intensive issue, has been through time a question for the jury. Finally, the Article calls into question the constitutionality of the exclusion of evidence, based on the defendant's right to a jury trial and his right to present his defense. Based on all of these considerations, this Article concludes that a defendant must be able to present evidence of self-defense to the jury, and the sweeping assertion in Kirkpatrick to the contrary is wrong.

\section{STATE V. KIRKPATRICK}

John Kirkpatrick and Garrod Farha went to Mulligan's Pub in Wichita, Kansas, late in the evening of January 22, 2004. ${ }^{5}$ At the bar,

1. KAN. STAT. ANN. § 21-3401(b) (2007).

2. Id. $\S 21-4219$ (b).

3. 184 P.3d 247 (Kan. 2008)

4. $\S 21-3219$.

5. Kirkpatrick, 184 P.3d at 252. 
they ran into mutual friends, Rob Powers and Thomas Wright. ${ }^{6}$ Two other friends of Powers were also at the bar, Jasen Tedlock and Jake Williams. $^{7} \quad$ The six men stayed at Mulligan's until closing time, approximately 1:45 a.m. ${ }^{8}$ Powers then invited his five friends and several others to come to his apartment. ${ }^{9}$

At Powers's apartment, a conversation among car racing enthusiasts became quite loud. ${ }^{10}$ Powers, worried about disturbing his neighbors, asked his guests to quiet down. ${ }^{11}$ The noisy conversation did not subside, and Powers admonished his guests that the next person who raised his voice had to leave. ${ }^{12}$ Thomas Wright was the next person, and Powers asked him to leave. ${ }^{13}$ Wright was not pleased, but he followed his host outside. ${ }^{14}$ Tedlock, Fahra, and Kirkpatrick followed along. ${ }^{15}$

While the five men were outside the apartment, Tedlock and Fahra started to argue, and Tedlock may have tried to hit Fahra, but actually hit Wright. ${ }^{16}$ A fight ensued, in which Kirkpatrick saw Tedlock draw a knife. $^{17}$ Powers physically restrained Tedlock. ${ }^{18}$ The argument and scuffle stopped only when Williams came outside and took Tedlock back indoors. ${ }^{19}$

Kirkpatrick, Fahra, and Wright left together. ${ }^{20}$ Other guests left as well. ${ }^{21}$ Williams and Tedlock stayed with Powers at the apartment. ${ }^{22}$

Kirkpatrick, Fahra, and Wright went to Fahra's apartment and got Fahra's dog, a large pit bull, and his roommate's gun. They then returned to Powers's apartment. ${ }^{23}$ Fahra gave Kirkpatrick the gun. ${ }^{24}$

\footnotetext{
6. Id.

7. $I d$.

8. Id.

9. Id.

10. Id.

11. Id.

12. $I d$.

13. $I d$.

14. Id.

15. $I d$.

16. $I d$.

17. Brief of Appellant at 3, Kirkpatrick, 184 P.3d 247 (No. 04-93465-5), 2005 WL 2395718.

18. Kirkpatrick, 184 P.3d at 252.

19. Id.

20. Id.

21. Brief of Appellant, supra note 17, at 3.

22. Id.

23. $I d$.

24. Id.
} 
Not surprisingly, there were conflicting accounts of the events that occurred upon the return of the three men. According to Powers, Wright had called him twice before the three actually arrived. ${ }^{25}$ The first call was to tell Powers that his face was bleeding; the second was to ask Powers to come outside. ${ }^{26}$ Wright denied talking to Powers, but did admit to trying to call, but that Fahra got through to Powers first. ${ }^{27}$ Kirkpatrick stated that Fahra and Wright were both trying to contact Powers. ${ }^{28}$ Be that as it may, Powers came outside and spoke with Wright, Fahra, and Kirkpatrick. ${ }^{29}$

According to Kirkpatrick, Powers and Fahra discussed the earlier scuffle in an attempt to smooth over the situation. ${ }^{30}$ Kirkpatrick thought all was well, until he looked through the apartment's sliding glass door. ${ }^{31}$ He testified that he saw Tedlock waving a .45 caliber semi-automatic pistol and yelling, "Where is Tom [Wright] at? Does he want more?"32 Kirkpatrick knew that Powers had such a pistol. ${ }^{33}$ Kirkpatrick pushed Powers out of the way, went up to the window and told Tedlock to put the gun away and that the situation was over. ${ }^{34}$ He also told the men outside that Tedlock had a gun, and Wright confirmed Kirkpatrick's testimony. ${ }^{35}$

Kirkpatrick also testified that Tedlock continued to curse, yell, and threaten, "I'll kill you," while looking at Kirkpatrick. ${ }^{36}$ Tedlock cocked the pistol and moved toward the front door of the apartment. ${ }^{37}$ Kirkpatrick fired three shots because he feared for his life and the lives of his friends. ${ }^{38}$ He believed that Tedlock would have come outside and shot them. ${ }^{39}$

Powers's version of these events differed. Powers testified that, when he came outside, Fahra was holding the dog. ${ }^{40}$ Powers asked what

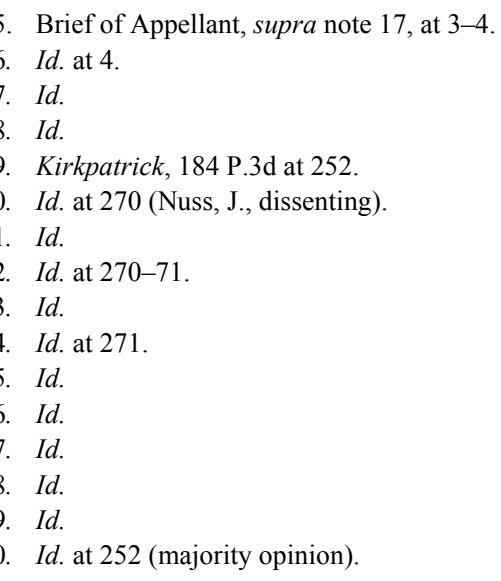


was going on and why had they come back with the dog. ${ }^{41}$ Powers stated that the men did not respond, but that Kirkpatrick pulled the gun from the waistband of his pants. ${ }^{42}$ Powers asked him why he had the gun and Kirkpatrick responded that he was representing his "set."43 Powers asked Kirkpatrick for the gun and tried to calm him down. ${ }^{44}$ Fahra was trying to kick down the door. ${ }^{45}$ Kirkpatrick fired one shot into the door of the apartment. ${ }^{46}$ Powers tried to grab the gun. ${ }^{47}$ Kirkpatrick shoved Powers away and shot twice more into the door. ${ }^{48}$

Tedlock testified, basically, that he took no part in this second argument. ${ }^{49}$ He saw a man with a dog outside the apartment. ${ }^{50}$ As he was closing the apartment window he had been looking out, someone tried to kick in the door. ${ }^{51}$ The door did not come open because the chain lock was engaged. ${ }^{52}$ Williams ran to the door, pushed it shut, and threw the deadbolt. ${ }^{53}$ Williams was hit by one of the shots fired through the door. ${ }^{54}$ Williams died from the gunshot wound. ${ }^{55}$

During a search of the house, law enforcement found a .45 caliber pistol in a closet, under a pile of clean linens. ${ }^{56}$ The gun was in its case, and the magazine was stored in a separate compartment in the case. ${ }^{57}$ The facts of the case do not indicate that any testing was done on the gun to try to determine if Tedlock had ever handled the gun.

Kirkpatrick was charged with felony murder, based on the underlying felony of criminal discharge of a firearm at an occupied dwelling, but he was not charged with the underlying felony. ${ }^{58}$ At trial, Kirkpatrick received a self-defense instruction, but did not receive jury instructions on lesser included offenses of felony murder. ${ }^{59} \mathrm{He}$ had

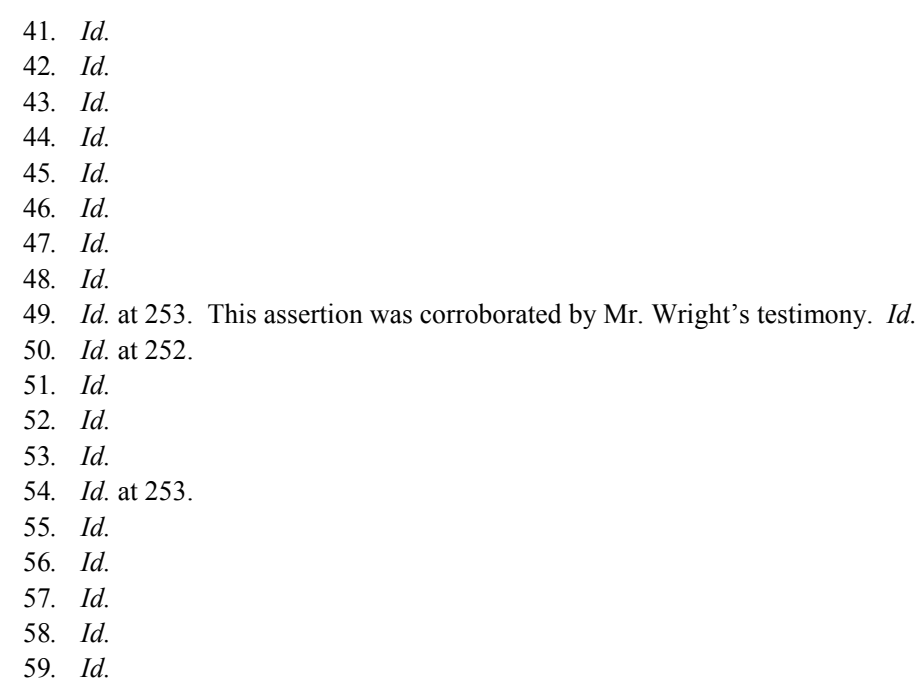


requested both voluntary manslaughter and reckless involuntary manslaughter. ${ }^{60}$ The trial court denied both requests, stating that there was no evidence of an intentional killing as required by voluntary manslaughter, and that there was no evidence of recklessness as required by reckless involuntary manslaughter. ${ }^{61}$ Kirkpatrick was convicted by the jury and then sentenced to life in prison. ${ }^{62}$

On appeal, Kirkpatrick challenged the trial court's failure to instruct the jury on lesser included offenses. ${ }^{63}$ Kirkpatrick's claim had two interrelated parts. First, since the trial court had instructed on selfdefense, evidence relating to the defense weakened the evidence of the underlying felony, and as a result would have permitted the trial court to instruct the jury on lesser included offenses. Second, giving lesser included offense instructions was also supported by the theory of "imperfect self-defense," which also should have been available since the jury was instructed on perfect self-defense. ${ }^{64}$

The Kansas Supreme Court, in a majority opinion authored by former Chief Justice McFarland, summarized Kirkpatrick's argument, cited the relevant law relating to lesser included offenses in felony murder cases, and, as the starting point of the analysis, stated that "Kirkpatrick was not entitled to a self-defense instruction" under K.S.A. 21-3214(1). ${ }^{65}$ That statute provides that self-defense is not a defense for a person who is the aggressor and "[i]s attempting to commit, committing, or escaping from the commission of a forcible felony." defined by statute, a forcible felony is "any ... felony which involves the use or threat of physical force or violence against any person." ${ }^{, 67}$ Based on case law and statutory construction, the crime of criminal discharge of a firearm at an occupied dwelling is a forcible felony. ${ }^{68}$

The Court analogized Kirkpatrick's case to State v. Bell, in which the defendant was charged with felony murder and criminal discharge of a firearm at an occupied vehicle. ${ }^{69}$ At Bell's trial, he requested a self-

60. Id.

61. Id.

62. Id.

63. Id.

64. Id.; Brief of Appellant, supra note 17, at 8-11.

65. Kirkpatrick, 184 P.3d at 253-54.

66. KAN. STAT. ANN. § 21-3214 (2007).

67. Id. § 21-3110(9) (Supp. 2008). “"Forcible felony' includes any treason, murder, voluntary manslaughter, rape, robbery, burglary, arson, kidnapping, aggravated battery, aggravated sodomy and any other felony which involves the use or threat of physical force or violence against any person." Id.

68. Kirkpatrick, 184 P.3d at 254-55.

69. Id. 
defense instruction, but was denied..$^{70}$ On appeal, the defendant asserted as error the trial court's failure to give the instruction. In Bell, the Kansas Supreme Court affirmed the trial court on the basis that criminal discharge was a forcible felony and that, applying K.S.A. 21-3214(1), the defendant was barred from asserting self-defense when charged with a forcible felony. ${ }^{71}$ The court in Kirkpatrick reasoned that, since Kirkpatrick was charged with committing felony murder with an underlying forcible felony, he was also not entitled to the self-defense instruction he received. ${ }^{72}$ The fact that Kirkpatrick had produced evidence relating to his theory of defense was immaterial.

Despite the apparent breadth of this analysis, the majority explicitly stated that its holding was limited to the facts of Kirkpatrick's case. ${ }^{73}$ The court stated: " $[\mathrm{t}]$ he policy behind the statute [K.S.A. 21-3214(1)] . . is well served under the facts of this case." 74 The recitation of facts that follows this declaration is confusing in two ways. First, the court makes credibility calls on the conflicting evidence. The court entirely dismisses Kirkpatrick's testimony about Tedlock's actions inside and his possession of a gun. Based on these credibility determinations, the court also concludes that Kirkpatrick and his friends were "[a]t all times during the events in this case... the aggressors." 75 As to the credibility determinations, those are not up to the court to make. As to determining that Kirkpatrick and his friends were the aggressors, that conclusion does not lead to a determination that the policy of K.S.A. 21-3214(1) is met in this case. K.S.A. 21-3214 contains separate provisions for initial aggressors and aggressors who try to provoke the use of force in order to use force in return. ${ }^{76}$ The majority appears to have combined the policies of all subsections in K.S.A. 21-3214 to come up with its conclusion. The court did not consider whether any of the policies of the other subsections of K.S.A. 21-3214 might apply, while making its decision rest on the first subsection.

Justice Rosen concurred in the result of the case, on the basis that the facts did not warrant a self-defense instruction and that "Kirkpatrick, being the initial aggressor should not have received a self-defense

70. State v. Bell, 80 P.3d 367, 373 (Kan. 2003), abrogated on other grounds by State v. Anderson, 197 P.3d 409 (Kan. 2008).

71. Id.

72. Kirkpatrick, 184 P.3d at 255.

73. Id. at 256

74. Id.

75. Id.

76. Kan. StAT. ANN. § 21-3214(2)-(3) (2007). 
instruction from the trial court." ${ }^{, 77}$ Justice Rosen expressly disagreed with the "sweeping declaration found by the majority that bars a selfdefense claim by a defendant charged with a forcible felony." 78 On the forcible felony issue, Justice Rosen observed that Kirkpatrick was engaged in several forcible felonies, including aggravated assault, at the time he fired the shots, and that the actual discharge of the firearm, the act alleged to have been in self-defense, should not have been the basis for barring the claim of self-defense. ${ }^{79}$ Justice Rosen's brief analysis is fully explored by the dissent.

The dissenting justices, Justice Nuss, joined by Justice Beier, took issue with the majority's sweeping declaration that "K.S.A. 21-3214(1) absolutely bars a self-defense claim once any defendant is merely charged with a forcible felony, regardless of the particular facts of a case," arguing that "this declaration produces absurd results, is contrary to the legislative purpose, and fails to address contrary Kansas law." 80 Justice Nuss made several points in dissent. He noted that there is Kansas case law that directly contradicted the majority's analysis, but which was not addressed at all by the majority. ${ }^{81}$ More importantly, Justice Nuss construed the self-defense statutes to bar self-defense "only if the accused is already otherwise committing a forcible felony when he or she commits a separate act of violence, i.e., in purported selfdefense." 82 In support of this conclusion, Justice Nuss cited many Kansas opinions, both recent and older, that analyzed the availability of self-defense in the context of a felony murder/underlying forcible felony. ${ }^{83}$ For example, he cited State $v$. Bell, the case heavily relied on by the majority, to illustrate his point. ${ }^{84}$ The defendant in Bell had pursued the victim in a car. He shot and killed the victim. The defendant sought to assert self-defense, but the trial court denied the requested instruction. Despite the language relied on by the majority, the court in Bell ultimately found that there was no evidence to support the

\footnotetext{
77. Kirkpatrick, 184 P.3d at 273 (Rosen, J., concurring).

78. Id.

79. $I d$.

80. Id. at 266 (Nuss, J., dissenting).

81. Id. at $266,270$.

82. Id. at 269.

83. Id.

84. Id. at 269-70 (citing State v. Bell, 80 P.3d 367 (Kan. 2003), abrogated on other grounds by State v. Anderson, 197 P.3d 409 (Kan. 2008)).
} 
requested instruction. ${ }^{85}$ In contrast, in Kirkpatrick's case, there was evidence that supported the assertion of self-defense. ${ }^{86}$

Justice Nuss also observed that a person asserting self-defense generally does not allege that she did not commit the act or acts that constitute the crime, but rather offers self-defense as a justification for the act. ${ }^{87}$ If the act was justified as self-defense, the person will not be convicted of the crime charged. The problem, then, with the majority's opinion, is that the actual charging of the forcible felony itself (i.e., the act claimed to be in self-defense) will act as a bar to the assertion of selfdefense: ${ }^{88}$

Additionally, under the majority's rationale, the following unfortunate situation could occur. If from A's house he fires multiple shots at B who is walking on the sidewalk, and to protect himself $\mathrm{B}$ returns fire toward A's house, killing A, then B can be charged with felony murder. The underlying felony would be the forcible felony of discharging a firearm at an occupied dwelling, and the State would successfully bar B from asserting self-defense. ${ }^{89}$

Justice Nuss correctly termed the results that could flow from the majority's opinion "absurd." 90

III. K.S.A. 21-3219

Compounding the problems raised by Kirkpatrick is a relatively new self-defense statute. In 2006, the Kansas legislature passed K.S.A. 213219 , which confers immunity from criminal prosecution on a person who lawfully acts in self-defense. ${ }^{91}$ "“Criminal prosecution' includes arrest, detention in custody and charging or prosecution of the defendant." ${ }^{92}$ Subsection (b) permits the investigation of the use of force, "but the agency shall not arrest the person for using force unless it determines there is probable cause for the arrest." 93 Finally, subsection (c), added in 2007, states that "[a] county or district attorney or other prosecutor may commence a criminal prosecution upon a determination

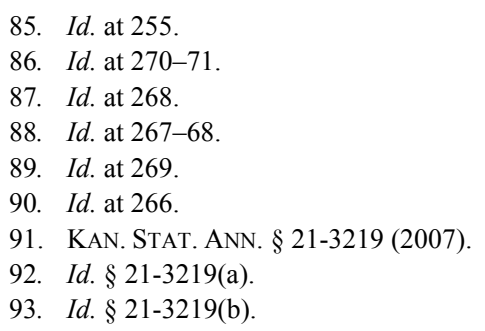


of probable cause." 94 The application of this statute has not been fully tested.

But, there has been one challenge to the commencement of a prosecution. In McCracken v. Kohl, the defendant was charged with several counts of aggravated battery. ${ }^{95}$ He challenged the filing of charges in a state habeas corpus motion, ${ }^{96}$ claiming immunity under K.S.A. 21-3219. ${ }^{97}$ Following an evidentiary hearing, the district court held that the defendant had not met his burden of proof to show that he was entitled to immunity. ${ }^{98}$ The trial court noted that its ruling would not affect whether or not the defendant was entitled to a self-defense instruction at trial. ${ }^{99}$

On appeal, the Kansas Supreme Court took up the case on its own motion. ${ }^{100}$ Leaving aside the procedural issues not on appeal, the Kansas Supreme Court agreed with the trial court that the defendant had not met his burden of proving immunity. ${ }^{101}$ The court realized that the statute itself had not been challenged and did "not offer any opinion on the statute's provisions or the burden of proof anomalies which it might create." 102 The court's decision left intact the trial court's observation that whether or not a self-defense instruction was to be given at trial was not a question answered in this case. ${ }^{103}$

\section{K.S.A. 21-3219 AND KIRKPATRICK COLLIDE: UNINTENDED CONSEQUENCES?}

K.S.A. 21-3219 anticipates that following an investigation, law enforcement and the prosecution will evaluate the facts as gathered and make a decision about whether or not a person who committed an act of force should be criminally charged or if she was acting lawfully in selfdefense and as a result is immune from prosecution. ${ }^{104}$ This statute was

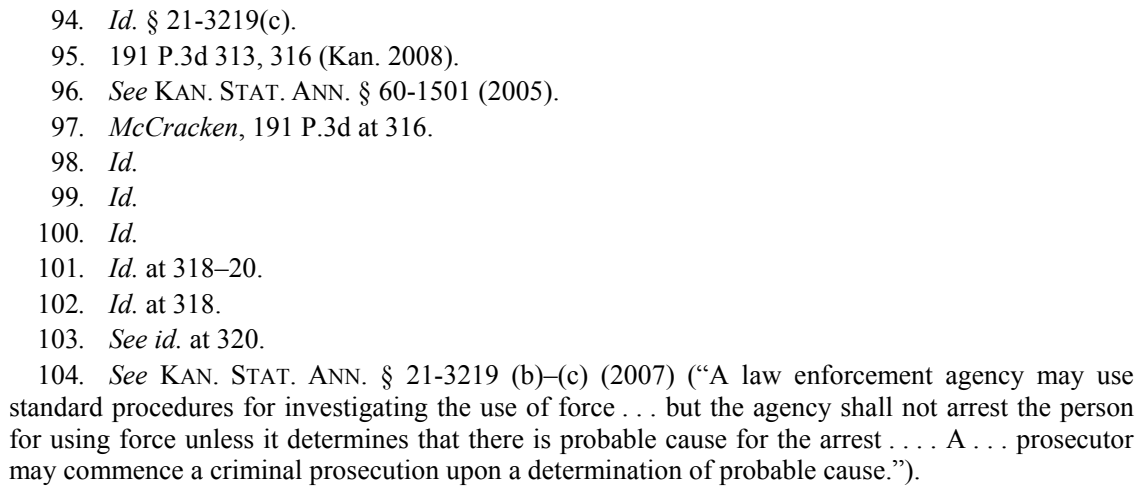


no doubt intended to provide even greater protection for those who act in self-defense. In "clear cut" cases of self-defense, as determined by law enforcement and the prosecutor, the person who used force will be spared the stigma and anxiety of arrest and prosecution. But how many of those "clear cut" cases are there?

Undoubtedly, there will be cases where, on review by law enforcement and prosecutors, probable cause for arrest and prosecution will be found and the prosecution will determine that the person is not immune from prosecution under K.S.A. 21-3219. The person will be charged, most likely, with a felony that can be classified as forcible, since acts of force lie at the heart of self-defense claims. Under Kirkpatrick, if the defendant is charged with a forcible felony, on its own or as the underlying felony for a felony murder charge, the defendant will not be able to assert self-defense, no matter how controverted the evidence. ${ }^{105}$ By judicial fiat, in a result not explicitly contemplated by the Kansas legislature, the traditional affirmative defense of self-defense has been severely truncated, if not eliminated entirely. The authority to believe or disbelieve a defendant's evidence of self-defense will no longer rest with the jury, but will rest with law enforcement and prosecutors. Based on the historical and current state of statutory, case, and constitutional law, this result is wrong.

\section{HISTORY OF SELF-DEFENSE}

The question of self-defense has historically been a jury question. The concept of self-defense, which took on legal significance in the twelfth century, was based on the idea that criminal liability should not be imposed for a person who is not morally blameworthy. Believing that natural law gave a person the right to protect himself from harm, if a person acted in self-defense and not with a guilty mind, an acquittal or a conviction of a lesser offense was appropriate. For the past several hundred years, the degree of culpability, if any, was a fact question reserved for the jury. To understand how self-defense evolved and why it must remain a jury question, it is helpful to trace the history of criminal liability.

The now-common Latin maxim actus non facit reum nisi mens sit rea-"an act does not make one guilty unless his mind is guilty"

105. See State v. Kirkpatrick, 184 P.3d 247, 255 (Kan. 2008).

106. See Joseph Goldstein et al., Criminal Law: Theory and Practice 767 (1974); Martin R. Gardner, The Mens Rea Enigma: Observations on the Role of Motive in the Criminal Law Past and Present, 1993 Utah L. Rev. 635, 635 (1993); Francis Bowes Sayre, Mens Rea, 45 HARV. 
not exist in primitive English criminal law. Prior to the twelfth century, criminal law was one of strict liability and the reason behind a person's actions was irrelevant. ${ }^{107}$ By simply committing a proscribed act, a person was held criminally liable. ${ }^{108}$ Thus, a man who killed an intruder to protect his family from certain death would receive the same punishment as the intruder would have received had the man stood by and permitted the intruder to kill his family. ${ }^{109}$ It was not until the Normans invaded England, bringing with them European notions of criminal liability, that England began to ponder the notion of strict liability. ${ }^{110}$

During the twelfth century, a resurgence in scholarship brought the principles of Roman and canon law to the forefront, which began to slowly influence the law of strict criminal liability. ${ }^{111}$ Ideas and legal terms from the Roman Code and Digest, which carefully considered the mental element of the crime, seeped into the writings of English common law scholars. ${ }^{12}$ The teachings of the church, that a guilty mind must be scrutinized as closely as the physical act, began to shape secular laws. ${ }^{113}$

Canon law had long incorporated an emphasis on the guilty mind. In 597, the writings of St. Augustine evidenced the development of mens rea. In addressing the crime of perjury, St. Augustine concluded that

L. REV. 974, 974 (1932).

107. Gardner, supra note 106, at 651-52; Sayre, supra note 106, at 979-81.

108. See Sayre, supra note 106, at 979-80; see also Paul E. Raymond, The Origin and Rise of Moral Liability in Anglo-Saxon Criminal Law, 15 OR. L. REV. 93, 117 (1936). Raymond finds evidence for the strict liability concept as late as 1118. Id. at 95. Quoting from a group of AngloSaxon laws, Raymond writes: "It is the law: one who does wrong unknowingly must suffer for it knowingly; for in this case a man cannot render an oath by law, that somebody has not been farther from life or nearer to death because of this act." Id.

109. Sayre, supra note 106, at 979-80. See also Raymond, supra note 108, at 96, wherein he postulates that perhaps reasons for disregard of intent in the very early history of English common law include (1) the difficulty of obtaining and evaluating proof, (2) the fact that criminal and civil law were not divided so that there were no tort remedies available, and (3) the lack of conception of the court as an impartial authority.

110. Cynthia K. Gillespie, Justifiable Homicide: Battered Women, Self-Defense, and THE LAW 31 (1989). Although not all scholars agree that self-defense was exclusively the result of the invasion of the Normans, as Gillespie seems to claim, it is not disputed that European notions of culpability came with the Normans to England.

111. See id. at 31-33. See also Raymond, supra note 108, at 102, wherein Raymond notes that early writings of the Norman period were not really laws, so much as collections of essays that demonstrated the "spirit of the times." Of interest here are the "laws" of William I: "If somebody kills another for blood vengeance or by self-defence he may not take anything of the dead, not his horse, helmet, sword, or any money; but he may cut in pieces his body as is customary to do with the slain." Id. at 103 (quoting Leges Henrici Primi, 83, 6).

112. Sayre, supra note 106, at $982-83$ (noting that Sir Henry Bracton borrowed heavily legal terms and maxims directly from the Roman notions of dolus and culpa, thereby sparking new examination of these legal concepts).

113. Id. at 983 . 
"“[n]othing makes the tongue guilty, but a guilty mind." "114 This passage translates: "[r]eum linguam non facit nisi mens rea." 115 By simply removing the word "linguam," St. Augustine's belief in the necessity of an evil mind was applied to all criminal conduct. ${ }^{116}$ The need for an evil mind or motive was also reflected in the issuance of penance, which was proportional to the state of mind of the sinner. ${ }^{117}$

Once canon law began to influence secular law, the Anglo-Saxon church became a powerful influence in the progression of the common law, albeit slowly at first. During the thirteenth century, as judges wrestled with the tension between strict liability and the morality of condemning a person who acted in self-defense, a shift in punishment occurred through the use of the king's pardon, which was formalized in the Statute of Gloucester in $1278 .^{118}$ According to the statute, if selfdefense was an issue in a homicide, the offender was tried, and if the jury determined that the offender committed the offense, he was convicted. Questions were then put to the jury as to whether the killing was committed "by misadventure or in self-defense" or by "malice aforethought." "119 If the jury deemed the killing to be in self-defense or by misadventure, the offender was entitled to seek a king's pardon. ${ }^{120}$ Thus, the man who killed the intruder to protect his family from certain death may have been guilty of murder and convicted, but his life could be spared through the king's pardon. ${ }^{121}$ In the course of time, the granting of pardons became such a matter of course that for the sake of

114. Raymond, supra note 108, at 110-11. Raymond explains that St. Augustine's writings were significant in that his writings consistently established the doctrine that an "evil motive makes the evil act, and good motive the good act." Id. Thus, the crime of perjury was not based simply upon the words uttered, but the "inclination of the mind toward falsehood." Id.

115. Id.

116. Id.

117. Sayre, supra note 106 , at 983 . Sayre later notes that while judges were largely swayed by the teachings of the church in deciding whether the state of mind of the offender resulted in a finding of guilt, the judges drew the line at physical conduct. See id. Despite the teachings of the penitential books that a guilty mind is sufficient to have sinned, judges did not find criminal liability based simply on the state of mind without corresponding conduct, or actus rea. See id.

118. Id. at 995; see also GILLESPIE, supra note 110, at 33.

119. Sayre, supra note 106, at 995-96; see also GILLESPIE, supra note 110, at 33 ("[I] n all cases of homicide in which accident or self-defense was an issue, the accused still had to be tried and, if found responsible for the death, convicted of murder.").

120. Sayre, supra note 106, at 995-96; see also GILLESPIE, supra note 110, at 33; Thomas A. Green, The Jury and the English Law of Homicide, 1200-1600, 74 MiCH. L. REV. 413, 428 (1976). Thomas explains that because self-defense rules were rigid, requiring the offender to be facing certain death, jury verdicts included a response that "the defendant "could not otherwise have escaped death." Id. (quoting C 260/13, no. 5 (1302)). Judges would sometimes question whether the juries did indeed find that the defendant could not have escaped certain death without physical retaliation. Id.

121. See Sayre, supra note 106, at 980; Gardner, supra note 106, at 655. 
expediency, juries were allowed to directly return not guilty verdicts and thus bypass the king's pardon. ${ }^{122}$

While struggling with the tension between strict liability and a guilty mind, questions of malice or moral blameworthiness began to appear. Henry Bracton ${ }^{123}$ began to develop the notion of malice within the framework of the guilty state of mind necessary for punishment. Bracton, in writing about arson, began to use words such as "premeditated" or "wickedly." Believing that a crime was not committed unless an intent to injure existed, Bracton wrote: "we must consider with what mind (animo) or with what intent (voluntate) a thing is done, in fact or in judgment, in order that it may be determined accordingly what action should follow and what punishment."124

Bracton's belief that moral blameworthiness was essential to guilt paved the way for self-defense to emerge as an affirmative defense. Bracton's discussions of self-defense and criminal culpability focused on two questions: (1) did the offender intend his conduct, and (2) did the purpose behind the conduct render him blameworthy. ${ }^{125}$ In the event that the offender killed only because he reasonably believed the victim was going to kill him, he was absolved from liability. ${ }^{126}$

The degrees of blameworthiness were later reflected in the changes in homicide law during the thirteenth, fourteenth, and fifteenth centuries. ${ }^{127}$ As mens rea became more important, homicides became

122. Sayre, supra note 106, at 996; see also Green, supra note 120, at 430-31. Green traced one jail delivery role covering the years 1351 to 1353 wherein 21 of 68 defendants committed a homicide in self-defense. $I d$. at 430 . Another role from 1351 to 1366 stated that 19 of 32 homicides were committed in self-defense, while a role from 1366 to 1371 said that 59 of the 157 homicides were in self-defense. Id. Finally, on a role from 1377 to 1385, 24 of the 199 homicides were in selfdefense. Id. However, of those 199, only 2 additional defendants were convicted of felonious homicide. Id. Green does caution that the statistics should be loosely relied on as it is impossible to tell the frequency of acquittal when self-defense was not alleged. Id.

123. Sir Henry Bracton was a cleric and judge whose writings heavily influenced development of common law. Gardner, supra note 106, at 655.

124. Sayre, supra note 106, at 985 (citing 2 BRACTON DE LEGIBUS ET CONSUETUDIRIBUS ANGLiAE 101b (George E. Woodbine ed., 1922)).

125. Gardner, supra note 106, at 661 n.125. Here Gardner discusses Bracton's view of selfdefense as perhaps reflecting the "orthodox" Anglo-American view that culpability is a two-step process that focuses on the intent to act and the blameworthiness of the act. Id. This explanation of self-defense aligns with an excuse theory. Gardner notes that perhaps we are wiser to address the issue as one of justification and not excuse. Id. The doctrine of excuse is generally reserved for those actions where the offender did not possess moral blameworthiness or the requisite mens rea. Id. Justification on the other hand does not negate mens rea, but the actus rea or the act. Id. In other words, justification theory states the intentional act was not criminal. Excuse theory is more appropriately relegated to the defenses of insanity or compulsion where the state has an interest in labeling the conduct illegal, but due to the absence of mens rea, the conduct is excused. See id.

126. Id.

127. Sayre, supra note 106 , at 994-97. 
separated by degrees based on the intent and seriousness of the conduct. $^{128}$ The first official statement addressing an acquittal by the jury based on self-defense came in 1532 with Enactment 24 of Henry VIII. ${ }^{129}$ Prior to 1532 , a convicted person who acted in self-defense and received a king's pardon still suffered the loss of property, goods, or chattel. ${ }^{130}$ Based on King Henry VIII's statute, a person could now defend his person and his home without fear of conviction or of losing his property, goods, or chattel. ${ }^{131}$ By the seventeenth century, when English common law was being recorded by the scholars of the time, mainly Edward Coke and Matthew Hale, self-defense could absolve the offender of all criminal and civil penalties. ${ }^{132}$

While in its infancy, America turned to English common law to lay the groundwork for our legal system. ${ }^{133}$ It was at this time that England began to publish judicial opinions and William Blackstone drafted the Commentaries on the Laws of England. ${ }^{134}$ Blackstone's treatise was the first publication that comprehensively set out the common law of England, and, being the only treatise of the day, it served as the only law book for the early American lawyers and judges. ${ }^{135}$ According to Blackstone, there were essentially two situations in which self-defense arose: the right of a person to defend himself, others, and his property from a sudden unprovoked attack, and the right of a person involved in a confrontation to defend himself. ${ }^{136}$ The second of these situations was a fact intensive inquiry that focused on whether the offender (1) was

128. Id. at 995 .

129. Rollin M. Perkins, Self-Defense Re-Examined, 1 UCLA L. REV. 133, 138 (1953). Perkins explains that while Hale believed the statute to be "declarative," Sir Michael Foster, in 1762, drew a sharp distinction between defensive killing of the one who started the attack and defensive killing which became necessary in the course of a "chance-medley." Id. Thus, three questions arose: (1) was the offender entirely free from fault?; (2) was there mutual combat where the adversary unexpectedly escalated the fight?; and (3) did the initial aggressor, who disengaged, retreat to the point that his back was against the wall? Id. at 138-39.

130. Id. at 142 .

131. Id. at 138 n. 30 .

132. GILLESPIE, supra note 110, at 33; see also Perkins, supra note 129, at 143. Perkins focuses on Hale's discussions and notes that homicide se defendo would still not completely absolve the offender of criminal liability. See also Gardner, supra note 106, at 669 (explaining that "in 1628, Coke defined murder as the unlawful killing of another with "malice fore-thought" (quoting EDWARD COKE, THIRD INSTITUTE 47 (1641))). It is interesting to note that first-degree murder under Kansas law does not require that malice be established, only that the homicide was premeditated and intentional. See KAN. STAT. ANN. § 21-3401 (2007).

133. GILLESPIE, supra note 110, at 39-40.

134. Id. at 40; see also Richard Singer, The Resurgence of Mens Rea: II-Honest But Unreasonable Mistake of Fact in Self Defense, 28 B.C. L. REV. 459, 465 (1987) (discussing an early American judicial decision that relied solely on Blackstone).

135. GILLESPIE, supra note 110, at 40.

136. Id. 
engaged in mutual combat, (2) was the initial aggressor, and/or (3) retreated "to the wall." 137

According to Blackstone, the first tenet of common law occurred when the offender was an innocent victim of a completely unprovoked violent attack or other felony crime. In such an instance, the victim had no obligation to retreat-and perhaps even a duty not to retreat. ${ }^{138}$ Because the prevention of the felony by the victim was seen as a part of his or her duty, the prevention of the felony was justified. ${ }^{139}$

The second tenet of self-defense involved mutual combatants where, during a quarrel, $\mathrm{A}$ and $\mathrm{B}$ entered into a physical fight which escalated to the level of use of deadly force. In the event that both A and B had access to deadly force and the killing occurred without a disengagement from the fight, the killing was chance-medley and the offender was guilty of manslaughter. In the event that A retreated before, but was pursued and killed B in self-defense, the homicide was se defendo and A was not criminally liable. ${ }^{140}$

Blackstone's, and to some degree Hale's, writings on self-defense law were utilized by the early American courts. ${ }^{141}$ Recorded cases from the nineteenth century are replete with examples of self-defense relying on common law rules. In 1886, L.B. Horrigan and Seymour D. Thompson published a volume addressing self-defense in a five volume set of defenses in criminal law. ${ }^{142}$ Of interest, for the purpose of this Article, are the chapters addressing the availability of self-defense when the offender is engaged in mutual combat and when the necessity for self-defense is produced by the offender.

A review of the cases from the nineteenth century reveals that while the early court drew upon the tenets of common law self-defense for guidance, the courts held defendants to a high standard and self-defense

137. Singer, supra note 134 , at 471-72; see also GILLESPIE, supra note 110 , at $38-40$ (discussing the medieval origins of self-defense and Blackstone's adoption of and changes to the doctrine). Singer provides an exhaustive discussion of the availability of self-defense when the offender was mistaken about the need for deadly force. See generally Singer, supra note 134. While mistake of fact is not the focus of this Article, Singer's discussion of common law self-defense is helpful.

138. Singer, supra note 134 , at 472 .

139. Id. at 471-72.

140. Id.

141. Id.

142. 1 L.B. Horrigan \& Seymour D. Thompson, Defences to Crime: The Adjudged CASES IN THE AMERICAN AND ENGLISH REPORTS WHEREIN THE DIFFERENT DEFENCES TO CRIMES ARE CONTAINED (San Francisco, Sumner Whitney \& Co. 1885). 
was not an easy path to acquittal. ${ }^{143}$ To begin, there was a distinction between justifiable and excusable homicide:

In the case of justifi[ed] self-defence, the injured party may repel force by force in defence of his person, habitation, or property, against one who manifestly intends and endeavors by violence or surprise, to commit a known felony upon either....

[I]t is justly considered that the right in such case is founded in the law of nature, and is not, nor can be, superseded by any law of society.

A homicide could be excused, although only barely, ${ }^{145}$ when a mutual quarrel precipitated the killing. In those instances, whether the offender was the aggressor or not, if the conflict escalated so that the offender's life was in danger, the offender must retreat as far as he could before the law would excuse the killing of his adversary. ${ }^{146}$ In the event that the offender committed the homicide se defendo or failed to retreat, the offender was guilty of manslaughter. ${ }^{147}$

143. Singer, supra note 134, at 471-74. Singer provides a good argument that early American courts misunderstood the two basic tenets of common law self-defense, which resulted in a confusion of whether a mistake of fact could prevent a successful defense. Id. According to Singer, the failure to appreciate the different types of self-defense introduced the reasonable person standard into American jurisprudence. Id. At common law, if the offender was mistaken about the facts-for example, it was discovered after the homicide that the victim was not armed-self-defense would still acquit the offender as they had no evil motive in killing. Id. Under early American jurisprudence, and in current Kansas statutes, the offender's belief that the use of deadly force was necessary must be reasonable. An objective standard is applied to reasonableness such that if the offender's mistake of fact is not reasonable, he is criminally liable.

144. Commonweath v. Riley \& Stewart (Boston Mun. Ct. 1837), in Reports of Criminal Cases, Tried in the Municipal Court of the City of Boston, Before Peter OxenBridge THACHER 471 (Horatio Woodman ed., Boston, Little \& Brown 1845), reprinted in HorRIGAN \& THOMPSON, supra note 142, at 156 .

145. Perkins, supra note 129, at 138; see also Singer, supra note 134, at 473.

146. Perkins, supra note 129, at 138; see also Singer, supra note 134, at 473. Singer takes issue with whether the early American courts continued to appreciate the difference between justifiable self-defense and excusable self-defense. Id. In the end, however, both Singer and the current authors agree that present day self-defense statutes abolish the distinction and treat justifiable and excusable all the same. As the focus of this Article is that self-defense should be resolved by the jury, we simply acknowledge the different position without further discussion.

147. Singer, supra note 134, at 473; see also GILLESPIE, supra note 110, at 42. Gillespie points to the introduction of the Colt revolver as a change in the perceptions about self-defense: it was not "manly" to shoot another man, and "“[r]eal' men, brave men, faced each other, eyeball to eyeball, and had it out in a fair fight." Id. In Commonwealth v. Riley \& Stewart, reprinted in HoRRIGAN \& THOMPSON, supra note 142, at 161-62, the court set forth the following law of mutual combat or aggression:

There is a species of self-defence known to the law, which, though involving fault to a certain extent, is yet excusable. The killing in such case is voluntary, the party having the intention to kill, or to do some great bodily harm at the time the death happened at least, 
In Stoffer v. State, ${ }^{148}$ the defendant, armed with a knife, pursued Webb with the intent to kill him. ${ }^{149}$ When Webb returned the attack, the defendant retreated to the house of a stranger and closed the door. ${ }^{150}$ Webb and his brother pursued the defendant, throwing rocks at the door and yelling "kill him!"151 When the two forcibly opened the door, the defendant stabbed and killed Webb. ${ }^{152}$ The trial court charged the jury that it could convict of manslaughter as the defendant was a mutual combatant, but refused to instruct that the killing of Webb could be excusable. ${ }^{153}$ The appellate court reversed for the failure to instruct the jury on the law of acquittal. ${ }^{154}$ The court held that evidence existed, which if believed, supported a finding that the defendant had abandoned the conflict and retreated, not just to the wall, but behind it. ${ }^{155}$

Although it may be obvious in Stoffer that the initial aggressor had sufficiently ended his assault and retreated, other cases are not so obvious. In Vaiden v. Commonwealth, ${ }^{156}$ the deceased and Vaiden were at Vaiden's house where a marriage was to take place. ${ }^{157}$ Vaiden and the deceased were playing cards when an altercation ensued based on the

but to have done it for the preservation of his own life. It arises from a sudden casual affray commenced and carried on in the heat of blood; and supposes that the person when engaged in such sudden affray, quits the combat before the mortal wound is given, and retreats or flies as far as he can with safety; and then, urged by mere necessity, kills his adversary for the preservation of his own life. This last supposed case borders very nearly upon manslaughter; and in fact and experience, the boundaries are in some instances scarcely perceivable; but in consideration of law they have been fixed. In both cases, it is supposed that passion has kindled on each side, and that blows have passed between the parties; but in the case of manslaughter, it is either presumed that the combat on both sides has continued to the time the mortal stroke was given, or that the party giving the stroke was not at that time in imminent danger. He, therefore, in the case of mutual conflict, who would excuse himself upon the ground of self-defence, must show that before a mortal stroke was given, he had declined any further combat, and retreated as far as he could with safety; and also that he killed his adversary through mere necessity, and to avoid his own immediate death. If he fails in either of these Id. circumstances, he will incur the penalty of manslaughter.

148. 15 Ohio St. 47 (1864), reprinted in HORRIGAN \& THOMPSON, supra note 142, at 213, overruled by Mead v. McGraw, 19 Ohio St. 55 (1869).

149. Id. at 214.

150. Id.

151. Id.

152. Id.

153. Id. at $214-15$.

154. See id. at 220 ("We think the Court erred in refusing to give each of the instructions requested, and also in the instructions given ....").

155. See id. at 219.

156. 53 Va. (12 Gratt.) 717 (1855), reprinted in HORRIGAN \& THOMPSON, supra note 142, at 222.

157. Id. at 222 . 
deceased's belief that Vaiden was cheating. ${ }^{158}$ Vaiden's wife reminded the deceased that there was to be no "fuss[ing]" that night and the deceased agreed. ${ }^{159}$ He left the house, but remained in the yard enraged and cursing. ${ }^{160}$ Vaiden picked up his gun and headed for the door. ${ }^{161}$ At the urging of his wife, Vaiden set the gun down and left the house. ${ }^{162}$ The deceased, who had left his gun behind, asked for his gun and it was handed out of the house by Vaiden's wife. ${ }^{163}$ The deceased then left. ${ }^{164}$

About 200 yards from the house, the deceased stopped to talk to Vaiden's son. ${ }^{165}$ As Vaiden approached, the deceased "suddenly exclaimed "yonder comes the $\mathrm{d} \_\mathrm{d}$ old rascal, and I'll frail him now." "166 The deceased "jumped over the fence, clubbed his gun about half-way of the barrel, and rushed" Vaiden. ${ }^{167}$ Vaiden told him to stop or he would shoot, but the deceased did not stop. ${ }^{168}$ As the deceased struck Vaiden twice with his gun, Vaiden shot and killed the deceased. ${ }^{169}$

The question presented was whether the deceased was the initial aggressor, and, if so, had he removed himself from the quarrel sufficiently to have ended the quarrel. ${ }^{170}$ The jury was also asked to resolve whether Vaiden sufficiently retreated to avoid further confrontation with the deceased or whether he re-initiated the conflict. ${ }^{171}$ Although the court mentions that Vaiden may have approached to protect his son, it points to the testimony that the son and the deceased seemed to be conversing quietly. ${ }^{172}$ Because facts existed that supported the jury's finding - that the defendant did not sufficiently retreat from the deceased's second act of aggression-the appellate court refused to overturn the jury verdict and absolve Vaiden of all culpability. ${ }^{173}$

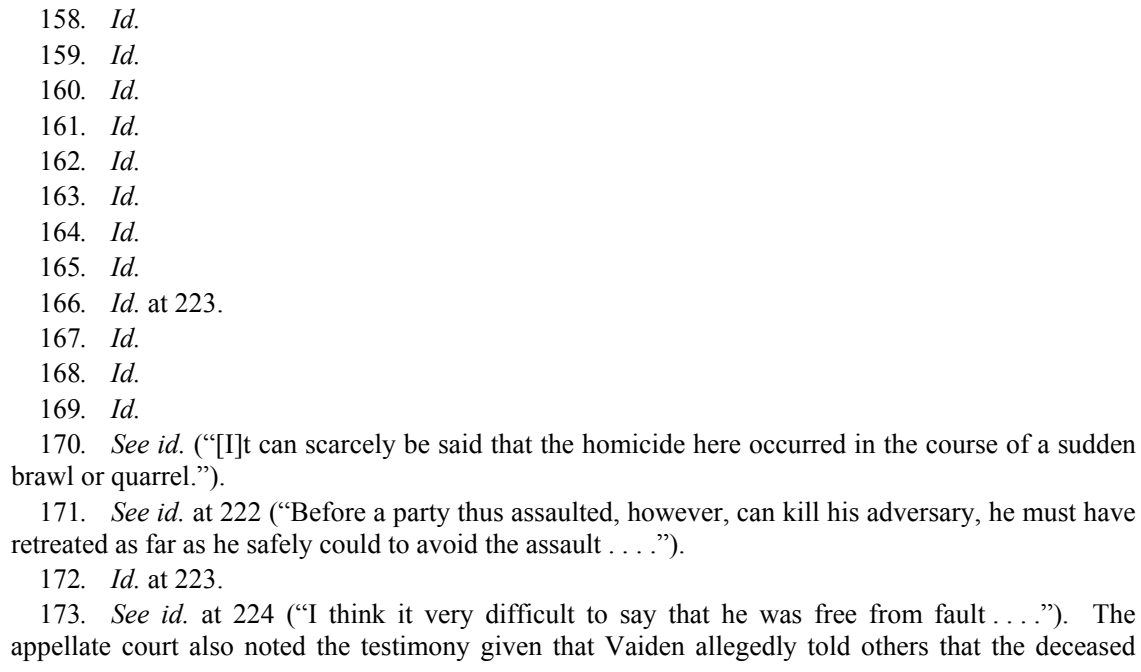

171. See id. at 222 ("Before a party thus assaulted, however, can kill his adversary, he must have retreated as far as he safely could to avoid the assault ...."). 
Much like self-defense issues that arise today - the questions of who was the aggressor and whether the initial conflict ended or whether the initial aggressor had sufficiently retreated from the conflict-were also the focus of older cases deciding criminal liability. ${ }^{174}$ Although modern self-defense statutes do not focus on justifiable or excusable homicide, but rather on self-defense and imperfect self-defense, the questions remain the same: who is blameworthy, and was the conduct justified by the facts surrounding the event?

The definition of self-defense in instances of mutual combat, or where the initial aggressor claims self-defense, has changed with the passage of state statutes and refocusing of policy. ${ }^{175}$ There are, however, still three threads that have consistently run through the doctrine of selfdefense for the last several centuries. First, self-defense was, and is, incredibly fact specific. Whether the conduct is considered justified or excused pivots on small, but crucial, facts. Such parsing of the fine details is still used to determine if the conduct was reasonable. ${ }^{176}$ Second, because facts drive the level of culpability, self-defense, like all fact questions, remains with the jury. The failure to instruct on selfdefense requires a new trial when evidence is presented, which if believed by the jury, would constitute self-defense. ${ }^{177}$ Third, the ability of a defendant to plead his lack of culpability based on self-defense is firmly entrenched in criminal law jurisprudence.

\section{KANSAS STATUTES AND CASE LAW}

As territories became states with independent governing bodies, the common law was codified by the state legislatures. In 1969, Kansas dispensed with the General Statutes Annotated and adopted the Kansas Statutes Annotated. Current principles of criminal liability are contained

should have been killed years ago. Id. The court found this piece of evidence significant in determining that Vaiden was not completely blameless. $I d$.

174. Even the facts were the same-fights over property, affairs, and territory.

175. The law today does not advocate for "real men" to fight fair. See GILLESPIE, supra note 110 , at 42 .

176. See State v. Ordway, 934 P.2d 94, 102 (Kan. 1997) (stating that there was evidence the defendant believed the use of force was necessary to defend his children but "[t]here [was] no evidence or even contention that his belief was reasonable").

177. See State v. Benham, 23 Iowa 154, 161 (1867) (arguing the jury should have been instructed on the elements of self-defense to properly decide the case); see also Stoffer v. State, 15 Ohio St. 47, 49 (1864) (ordering the judgment reversed and remanded because the court refused to allow the jury to consider self-defense), reprinted in HORRIGAN \& THOMPSON, supra note 142, at 215, overruled by Mead v. McGraw, 19 Ohio St. 55 (1869) (stating that the circumstances necessary to establish self-defense were present and "the jury should have been instructed to consider these circumstances" (construing Benham, 23 Iowa 154)). 
in Article 32 of Chapter 21. As the Kansas courts interpret and apply the statutes, some of the basic principles of common law and the rules applied in the nineteenth century still exist.

The analysis of self-defense begins with K.S.A. 21-3211, which authorizes the use of force to protect one's self or others. ${ }^{178}$ The statute is divided into two parts. Subsection (a) states that "[a] person is justified in [using] force when and to the extent it appears to such person and such person reasonably believes that such force is necessary to defend [against another's] imminent use of unlawful force." Subsection (b) permits the use of deadly force if the person "reasonably believes [that] deadly force is necessary to prevent imminent death or great bodily harm." ${ }^{180}$ A key element of the statute is whether the use of force, whether deadly or not, was reasonable. Only if the jury finds the belief reasonable is the offender entitled to an acquittal. If the jury determines the belief is not reasonable, the homicide would be classified as manslaughter. ${ }^{181}$

\section{KAN. Stat. ANN. § 21-3211 (2007).}

179. §21-3211(a).

180. $\S 21-3211$ (b). Similarly, K.S.A. 21-3212 permits a person to defend his home or occupied vehicle from unlawful intrusion as is reasonably necessary. $I d . \S 21-3212$. The property owner is allowed to meet force with force as long as the property owner's belief that a third party is attempting unlawful entry into his dwelling or vehicle was reasonable. $I d$. The same holds true for the use of deadly force. Id. A property owner can meet deadly force with deadly force as long as the property owner's belief in imminent death or great bodily harm is reasonable. Id.

181. Compare State v. Ordway, 934 P.2d 94, 100-01 (Kan. 1997), with State v. Decklotts, 19 Iowa 447 (1865), quoted in State v. Kennedy, 20 Iowa 569 (1866), reprinted in HoRRIGAN \& THOMPSON, supra note 142 , at 112 n.h. In State v. Decklotts, the deceased and some of his companions were "out for a spree" on Christmas Eve when they stopped by the saloon owned by Decklotts. HORRIGAN \& THOMPSON, supra note 142, at 112 n.h. After drinking at the saloon, the party left and proceeded to visit other saloons. Id. During the course of the evening, the deceased and his companions learned that Decklotts accused the deceased of stealing tumblers. Id. Late that evening the deceased and his companions returned to Decklotts's saloon. Id. The saloon, part of which was Decklotts's house and a grocery store, "was still open." Id. It is in dispute whether the deceased and company broke in or if the saloon was unlocked. Id. They confronted Decklotts about the accusation of stealing tumblers while Decklotts was behind the counter. Id. at 113. A quarrel ensued and the deceased accosted Decklotts. Id. It is disputed whether the deceased was reaching for his breast pocket for a weapon when Decklotts shot the deceased. Id. Decklotts was subsequently convicted of second degree murder and sentenced to sixteen years in prison. Id. at 115 .

In affirming the conviction, the appellate court emphasized that although the deceased and his companions were the aggressors, Decklotts was not permitted to use deadly force:

The occurrence is truly a most unfortunate one. The conduct of the deceased was highly blameworthy. He it was that provoked the difficulty, instigated, doubtless, by the liquor which he drank, and to the use of which he became a victim. The only mitigation his conduct finds, if it finds it at all, is in the fact that he was intoxicated, and in part by liquor sold him by the defendant. It would not do to hold that a saloon keeper may sell a man that which steals away his senses, overthrows his judgment and clouds his reason, makes him boisterous, quarrelsome and offensive; and then, himself being in no serious danger, shoot him dead because he is unreasonable, insulting and quarrelsome. 
Based on K.S.A. 21-3211, the Kansas Supreme Court applies a two prong test for determining when self-defense is applicable. ${ }^{182}$ The first prong is subjective and merely asks whether the defendant "sincerely believe[d]" that the use of deadly force was necessary to protect himself or another. ${ }^{183}$ The second prong employs an objective test and asks whether the defendant's sincere belief was reasonable. ${ }^{184}$ Under the objective prong, the defendant must be able to show the existence of facts that would support his belief. ${ }^{185}$ If the evidence exists, then the trial court must instruct on self-defense. ${ }^{186}$

The reporters contain numerous cases deciding whether evidence existed that would support a self-defense instruction. In some instances, the court has deemed that there is no evidence and the failure to give a self-defense instruction was not erroneous. ${ }^{187}$ Other cases hold the opposite. It is important to note, however, that in all the cases, the court cites to the same language for the level of proof: "the test is not how much [evidence there is] but is there any." "In the event that there is any evidence, even though it may be "slight and may consist solely of the defendant's own testimony," the jury must be instructed on selfdefense-even if it is not requested. ${ }^{189}$ Whether the evidence is sufficient to establish self-defense is then a question for the jury. ${ }^{190}$

State v. Hill ${ }^{191}$ involved a fight that took place at a crowded bar in Wichita. Upon entering the bar, there was a long, dark hallway filled with about twenty-five people trying to get in or out of the bar. ${ }^{192}$ As a result of the overcrowding, there was a lot of pushing and shoving. The victim, Patricia Jackson, began yelling at Hill for pushing into her. ${ }^{193}$ Hill allegedly apologized, but Jackson continued her verbal assault and began to hit and elbow Hill. ${ }^{194}$ Hill admitted she yelled, "I'm sick of this

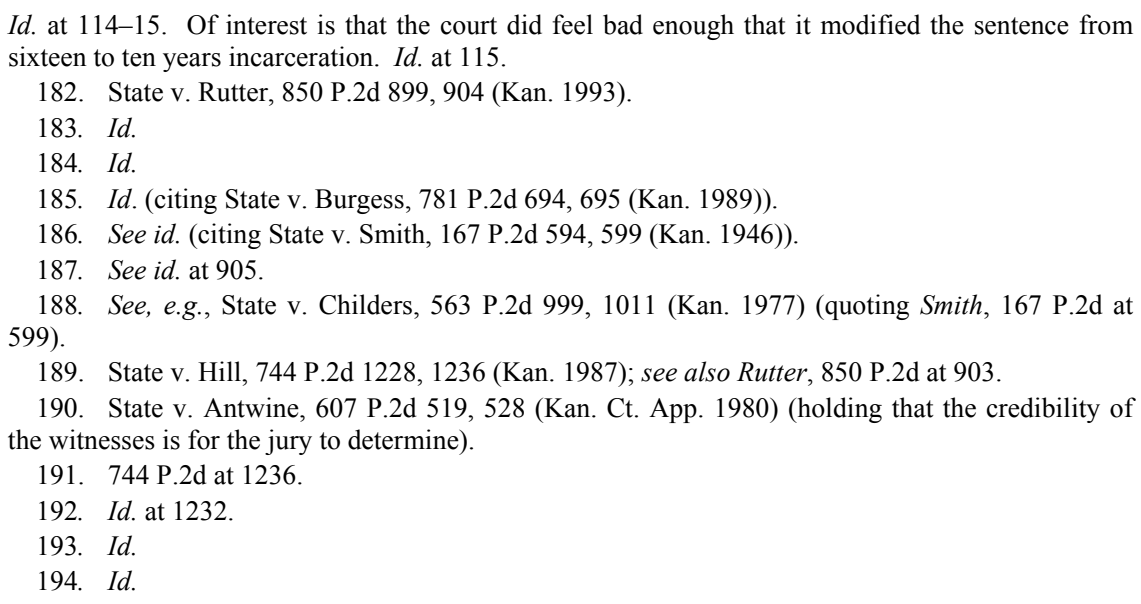


shit," and that she could not see Jackson's hands. ${ }^{195}$ Hill shot Jackson and testified at trial that she was afraid for her life. ${ }^{196}$ The trial court refused to instruct on self-defense or manslaughter and the Kansas Supreme Court reversed. ${ }^{197}$ Acknowledging that it was not probable or even likely that Hill was acting in self-defense, the court stated that this was not the issue:

The issue is whether there is any evidence supporting [the] defendant's statement that the force she used was necessary to defend herself. Because, viewing all the evidence in the record in the light most favorable to the defendant, there is some evidence of physical aggression on the part of Jackson, and some evidence of a fear of assault on the part of the defendant, an instruction on self-defense should have been given. ${ }^{198}$

In addition to the "innocent" bystander, Kansas statutes adopt, in some fashion, the common law rules regarding the use of self-defense by an aggressor. K.S.A. 21-3214 denies the protection of self-defense to an aggressor who is "attempting to commit, [is] committing, or [is] escaping from the commission of a forcible felony." ${ }^{199}$ Nor can a person intentionally provoke another as an excuse to rely on self-defense as protection from criminal liability. ${ }^{200}$ The only two instances in which an aggressor can lawfully use force against another are (1) if the aggressor "is in imminent danger of death or great bodily harm, and he has exhausted every reasonable means to escape," ${ }^{, 201}$ or (2) the aggressor "withdraws from physical contact... and indicates clearly... that he desires to withdraw and terminate the use of force, but the assailant continues or resumes the use of force."202

Much as it was at common law, the questions surrounding whether a defendant may use force when he is alleged to be the aggressor are incredibly fact-specific, with the decision often turning on the details. We begin with the threshold of "who is an aggressor?," a question that Kansas places in the hands of the jury. ${ }^{203}$ In State $v$. Antwine, the

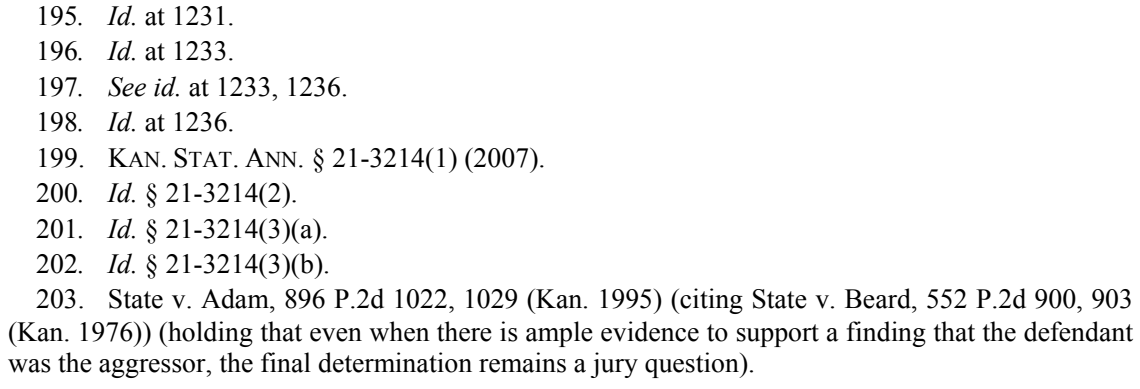


defendants were charged with twelve counts of aggravated robbery and each was convicted of one count of robbery. ${ }^{204}$ The incidents arose out of a dice game. ${ }^{205}$ According to the State, the defendants, armed with a sawed-off shotgun, robbed fourteen people who were at the game. ${ }^{206}$ According to the defendants, they went to the game with loaded dice, intending to cheat; they were successful in their use of the loaded dice, winning cash and jewelry. ${ }^{207}$ Weber, the house man, accused them of cheating and pulled a gun on them; Antwine allegedly hit Weber in the head and the two fled the scene with the money, jewelry, and Weber's gun. ${ }^{208}$ Antwine's request that a self-defense instruction on the use of force that was used to elevate theft to aggravated robbery was denied. ${ }^{209}$

In reversing the conviction on other grounds, the Kansas Supreme Court took time to discuss the trial court's failure to instruct on selfdefense. $^{210}$ The court held that if the jury believed that Weber pulled a gun on Antwine, then he was entitled to defend himself. ${ }^{211}$ The court stated that the State's evidence that Antwine was committing a forcible felony, the aggravated robbery, was not the only evidence to be evaluated. $^{212}$ If the jury believed the defendants' claim that they did not rob the people at the game, but merely cheated them out of their money, the defendants were not committing a forcible felony and Antwine was entitled to a self-defense instruction. ${ }^{213}$

\footnotetext{
204. 607 P.2d 519, 522 (Kan. Ct. App. 1980).

205. Id. at 523 .

206. Id.

207. Id.

208. Id. at 523-24.

209. Id. at 523 .

210. Id. at 526-29.

211. Id.

212. Id.

213. Id. at 528-29. But cf. State v. Wells, 1 N.J.L. [Coxe] 424 (1790), reprinted in HoRRIGAN \& THOMPSON, supra note 142, at 145 . Wells was involved in a dispute with the deceased over a turkey that Wells believed the deceased owed him. Id. at 146. Wells went to the deceased's home. Id. The deceased was at the blacksmith's, but was told by his wife which turkey Wells could have. Id. Wells retrieved a different, much better, turkey and left. Id. Later that day, needing a shovel repaired, Wells went to the blacksmith's shop where the deceased engaged him in an argument over the turkey. Id. at 146-47. The argument escalated and the deceased struck Wells, grabbed his hair and waist, and ran him into the corner of the shop. Id. at 147. The blacksmith separated the two, but the quarrel began again. Id. The deceased struck Wells and he fell against the wall. Id. Wells picked up a club and struck the deceased, killing him. Id.

Wells was tried and convicted of manslaughter. Id. at 150. His conviction was upheld on the grounds that he was a mutual combatant and there was no necessity for the fatal blow. Id. Despite the testimony that Wells was cornered and could not have retreated further, the court focused on the lack of a weapon in the deceased's possession and that Wells "could manage the deceased as he pleased, and that [the deceased] was no more than a child." Id. at 151.
} 
In those instances where the defendant is clearly the aggressor, the statutes and case law require the question of whether the aggressor was unable to escape or had withdrawn from the crime be put to the jury. Such is true even if the crime charged is one of felony murder. If evidence exists from which the jury could conclude that the requirements of K.S.A. 21-3214(3) are satisfied as to the underlying felony, then the self-defense instruction is available to the defendant and instructions must be given. ${ }^{214}$

State v. Sullivan involved a felony murder wherein the defendant was accused of attempting to burglarize Moore's house when he shot and killed Moore's brother. ${ }^{215}$ The State contended that Sullivan and his brother planned a burglary of Moore's house and Sullivan took a gun with him. ${ }^{216}$ While waiting for an opportunity to enter the house, Sullivan shot the victim because "'he seen me.",217 Sullivan testified that he went to Moore's house to retrieve belongings that Moore had taken from Sullivan's own house. ${ }^{218}$ After waiting for an opportunity to enter Moore's house, Sullivan and his brother decided to leave. ${ }^{219}$ At that time, Sullivan heard Moore let his dog outside. ${ }^{220}$ Sullivan knew the dog was a Doberman Pinscher trained to attack; when the dog advanced on him, he shot at it. ${ }^{221}$ He then heard somebody inside the house say that Lonnie, Moore's brother, was dead. ${ }^{222}$ The trial court's jury instruction denied a self-defense claim. ${ }^{223}$

On appeal, the defendant argued that he was entitled to a self-defense instruction on the grounds that he took "no overt act toward a burglary," that he was "withdrawing at the time that the shots were fired," and that he believed he was "in imminent danger from the attack of a vicious trained guard dog." 224 In reversing the case, the Kansas Supreme Court completely bypassed the fact that the crime alleged was felony-murder, and held it was "a jury question whether there was a completed crime or a thwarted intent, unless the evidence is so conclusive as to preclude

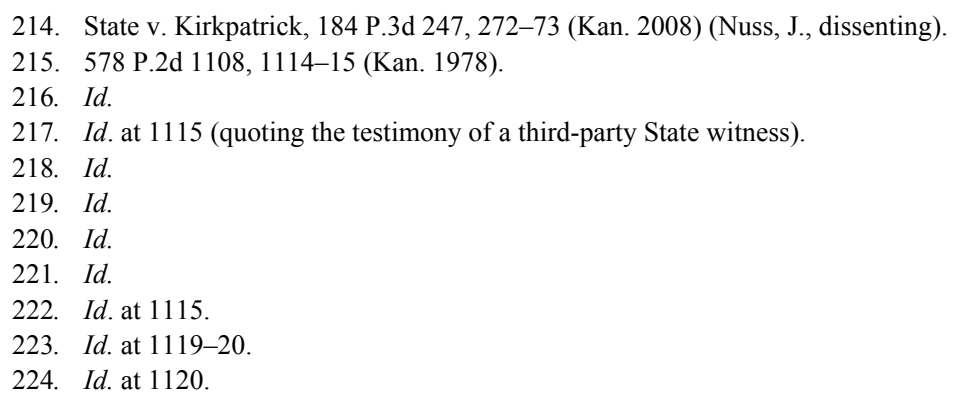


submission of one in favor of the other."225 Noting that the case presented conflicting evidence, Sullivan was "entitled to an instruction on [his] theory of the case even though the evidence introduced thereon [was] slight and supported only by defendants' own testimony."226

Based on well-established self-defense jurisprudence, the recent Kansas Supreme Court decision in State v. Kirkpatrick is not only perplexing, it is wrong. Kirkpatrick ignores decades of case law repeatedly holding that if there is any evidence to support self-defense, even if it is improbable that the jury would find in the defendant's favor, the instruction must be given. ${ }^{227}$ The Kirkpatrick court's obsession with the felony-murder rule does not change the analysis. As in Sullivan, if there is evidence of self-defense as to the underlying felony, the instruction must be given. If the court did indeed intend Kirkpatrick to be narrow in its holding, it failed, turning well-established Kansas statutes and case law "on its head." 228

\section{Right to A JURY TRIAL AND Right to PRESENT A DEFENSE}

Perhaps the most troubling aspect of the collision between Kirkpatrick and K.S.A. 21-3219 is the fact that this case law/statutory combination seems to reduce or eliminate the historic role the jury should play in deciding questions of self-defense. The decision on the validity of the defense now seems to lie with law enforcement and prosecutors. In those cases where the evidence of self-defense is conflicting, and the prosecution charges a person with a forcible felony, there will be serious questions about the defendant's ability to present his theory of defense at trial. These questions have constitutional implications.

The jury trial is at the heart of the American adversarial system of criminal justice. One foundational purpose for the jury trial is to protect the accused from overreaching government actors. ${ }^{229}$ The decision of a criminal defendant to proceed to jury trial reflects a desire both to put the State's case to the constitutionally-required test of proof of each element beyond a reasonable doubt, ${ }^{230}$ and to have the jury, as a reflection of the

225. Id.

226. Id. at 1120.

227. See, e.g., State v. Gayden, 910 P.2d 826, 834 (Kan. 1996) (citing State v. Hill, 744 P.2d 1228 (Kan. 1987)).

228. State v. Kirkpatrick, 184 P.3d 247, 271 (Kan. 2008) (Nuss, J., dissenting).

229. Duncan v. Louisiana, 391 U.S. 145, 155 (1968).

230. In re Winship, 397 U.S. 358, 364 (1970) (citing Speiser v. Randall, 357 U.S. 513, 525-26 (1958)). 
community, assess the validity of the defendant's asserted defense. A jury determines the fundamental questions of whether a defendant is criminally culpable at all and what level of culpability the State has proved. A jury trial gives the defendant her basic due process guarantee of an opportunity to be heard. ${ }^{231}$

Two separate constitutional provisions protect the defendant's right to a trial by jury. Article III provides that "[ $\mathrm{t}]$ he Trial of all Crimes . . shall be by Jury; and such Trial shall be held in the State where the said Crimes shall have been committed." ${ }^{\text {,32 }}$ The Sixth Amendment emphasizes that "[i]n all criminal prosecutions, the accused shall enjoy the right to a speedy and public trial, by an impartial jury of the State and district where in the crime shall have been committed."233 Because of the fundamental nature of the jury trial in the American criminal justice system, Duncan v. Louisiana ${ }^{234}$ incorporated the right to jury trial against the states. As explained by the Court in Duncan:

The guarantees of jury trial in the Federal and State Constitutions reflect a profound judgment about the way in which law should be enforced and justice administered. A right to a jury trial is granted to criminal defendants in order to prevent oppression by the Government.... Providing an accused with the right to be tried by a jury of his peers gave him an inestimable safe guard against the corrupt or overzealous prosecutor and against the compliant, biased or eccentric judge. ... Fear of unchecked power ... found expression in the criminal law in this insistence upon community participation in the determination of guilt or innocence.

The Court recognized that the states each have the right and responsibility to define crimes and punishments and to determine evidentiary and procedural matters. ${ }^{236}$ But the Sixth Amendment has specific requirements for the jury trial: for example, the rights to confrontation, to call witnesses, and to have the assistance of counsel. ${ }^{237}$ Due Process requirements add other basic requirements, including the

231. Chambers v. Mississippi, 410 U.S. 284, 294 (1973) ("The right of an accused in a criminal trial is, in essence, the right to a fair opportunity to defend against the State's accusations.").

232. U.S. CONST. art. III, $\S 2$, cl. 3 .

233. U.S. CONST. amend. VI.

234. 391 U.S. 145 (1968).

235. Id. at 155-56 (footnotes omitted).

236. See, e.g., Crane v. Kentucky, 476 U.S. 683, 690 (1986).

237. U.S. CONST. amend VI. 
accused's opportunity to be heard. ${ }^{238}$ Overall, the Court finds that these rights ensure a person the right to present a defense. ${ }^{239}$

Often a state's statutes or case law will conflict with or inhibit the defendant's right to present her defense. It is at this point of conflict that the Court will make constitutional determinations. In these cases, the Court has weighed the State's traditional role as the arbiter of crime and punishment with the accused's right to present a defense. In the final analysis, in many of these cases, the State's rule of exclusion or other evidentiary or procedural bar will have to yield to the defendant's right to present her defense. ${ }^{240}$ The court cases discussing the defendant's right to present a defense often are concerned with evidence that goes to the basic issue of whether or not the State is prosecuting the right person and whether the person is liable for the crimes charged, and whether the State can prohibit the introduction of exculpatory evidence. ${ }^{241}$

Two cases illustrate the Court's approach to resolving these conflicts. In Chambers v. Mississippi, Chambers was being tried for killing a law enforcement officer. ${ }^{242}$ Prior to Chambers's trial, a man named Gable McDonald confessed to committing the crime. ${ }^{243}$ He made statements to several people, including making a sworn statement to Chambers's trial attorney. ${ }^{244}$ However, at the preliminary hearing, McDonald recanted his confession. ${ }^{245}$ At trial, Chambers wanted to present evidence from McDonald about his confession and evidence from others who heard him confess. ${ }^{246}$ Chambers was permitted to call McDonald and examine him. ${ }^{247}$ The State cross-examined McDonald about his recantation. ${ }^{248}$ On redirect, Chambers sought permission to treat McDonald as a hostile witness. ${ }^{249}$ The trial court denied the request, finding that although McDonald was hostile, he was not adverse. ${ }^{250}$ In addition, a Mississippi common-law rule did not permit a party to

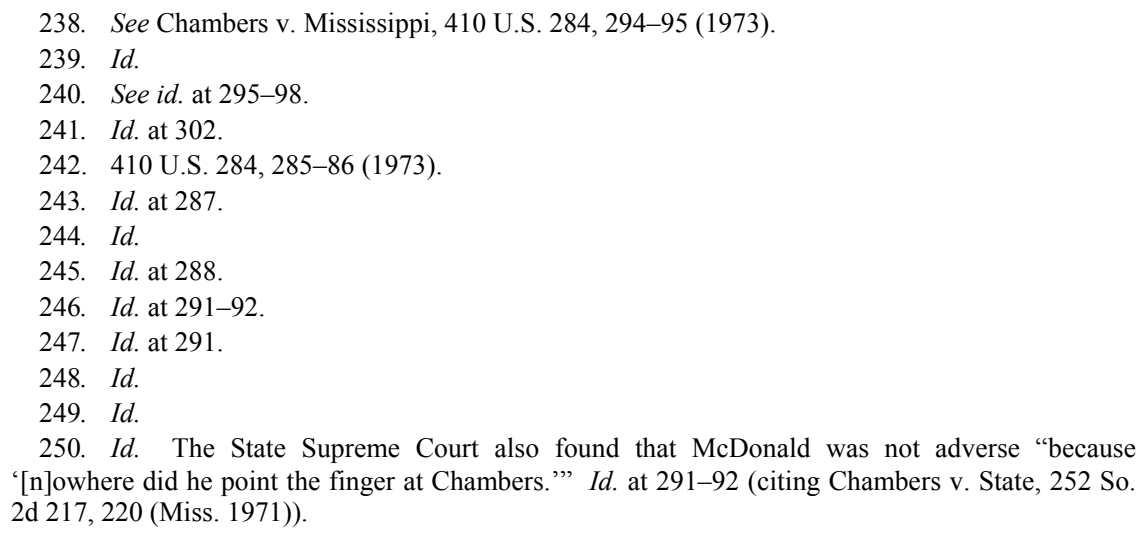


impeach its own witness. ${ }^{251}$ As to the other witnesses, the trial court refused to let them testify, finding that the testimony would be either inadmissible hearsay or an impermissible attempt to impeach Chambers's own witness, McDonald. ${ }^{252}$ Mississippi's hearsay rules recognized an exception for declarations against pecuniary interest, but not against penal interest. ${ }^{253}$

Chambers objected to all of these rulings on the constitutional grounds that they denied him of due process. ${ }^{254}$ The Supreme Court agreed:

The right of an accused in a criminal trial to due process is, in essence, the right to a fair opportunity to defend against the State's accusations. The rights to confront and cross-examine witnesses and to call witnesses in one's own behalf have long been recognized as essential to due process....

"A person's right to reasonable notice of a charge against him, and an opportunity to be heard in his defense - a right to his day in courtare basic in our system of jurisprudence; and these rights include, as a minimum, a right to examine the witnesses against him, to offer testimony, and to be represented by counsel.".25

The Court struck down the use in this case of both the "voucher rule" and the refusal to admit otherwise relevant evidence by "mechanistically" applying a state hearsay rule. ${ }^{256}$ The Court did note, however, that the defendant had to abide by established rules of procedure and evidence designed to assure both fairness and reliability in the ascertainment of guilt or innocence. ${ }^{257}$

In Crane v. Kentucky, Crane confessed to numerous crimes, including the charge in this case of killing a liquor store clerk during a robbery. ${ }^{258}$ He moved to suppress his confession alleging that it was not voluntary, but the trial court, following a hearing, held that the confession was voluntary and admissible. ${ }^{259}$ At trial, Crane wanted to challenge the credibility of his confession by introducing evidence of the conditions in which the confession was taken. The trial court excluded

251. Id. at 295 .

252. Id. at $292-93$ n.6.

253. Id. at 299 .

254. Id. at $289-90$.

255. Id. at 294-95 (quoting In re Oliver, 333 U.S. 257, 273 (1948)).

256. Id. at 296-98, 302 .

257. Id. at 302 .

258. 476 U.S. 683,684 (1986).

259. Id. at $684-85$. 
Crane's evidence, finding that because it was basically the same evidence considered in the suppression hearing, it could not come in at trial. ${ }^{260}$ The Supreme Court did not find this to be a difficult case. In a unanimous opinion, the Court reversed the state court's rulings and stated that as part of Crane's defense, which included drawing the credibility of his confession into question, he should have been permitted to introduce evidence relating to the conditions of his confession: ${ }^{261}$ "In the absence of any valid state justification, exclusion of this kind of exculpatory evidence deprives a defendant of the basic right to have the prosecutor's case encounter and 'survive the crucible of meaningful adversarial testing." "'262

Although a defendant asserting self-defense is admitting to the commission of an act of force, she is asserting that she is not criminally liable for that action and should be acquitted. Her evidence is exculpatory. Neither Kirkpatrick nor K.S.A. 21-3219 is a "valid state justification" for excluding a defendant's exculpatory evidence of selfdefense. In Kansas, all relevant evidence is admissible. ${ }^{263}$ Relevant evidence is that which has "any tendency in reason to prove any material fact." ${ }^{264}$ Facts that go directly to the defendant's criminal culpability are surely material. Kansas's liberal rule of admissibility is tempered by the statutes governing the admission and exclusion of evidence. ${ }^{265}$ In general, rules of evidence are an attempt to ensure that a trial is conducted in a manner that focuses the jury's attention on the issue presented by the case, not on extraneous issues, and to ensure that reliable evidence is admitted. Evidence relating to criminal culpability cannot be deemed extraneous.

As discussed above, self-defense holds a place as a fundamental affirmative defense in Kansas. The statutory provisions relate both to factual issues-whether the defendant is the initial aggressor or has provoked the use of force in order to respond in kind-and legal limitations - whether the defendant been charged with a forcible felony. Until K.S.A. 21-3219 and Kirkpatrick, there was no question in Kansas that if a defendant chose to go to trial and could produce some evidence

\footnotetext{
260. Id. at $685-86$.

261. Id. at $688-91$.

262. Id. at 690-91 (quoting United States v. Cronic, 466 U.S. 648, 656 (1984)).

263. Kan. STAT. ANN. § 60-407(f) (2005).

264. Id. §60-401(b).

265. See State v. Gunby, 144 P.3d 647, 654 (Kan. 2006) (discussing admission of evidence under Kansas's evidence statutes).
} 
of self-defense, that most questions relating to self-defense and its applicability were left to the jury.

Despite clear constitutional protection for the defendant's right to present her theory of defense, the United States Supreme Court has never held that any particular affirmative defense must be available as a matter of constitutional law. The Court has met affirmative defense issues as presented and many have been presented as burden of proof cases, assuming rather than deciding that the defense is or should be available. $^{266}$ If state law has made the defense available, the constitutional questions often concern which party assumes the burdens of production and persuasion, and what level of proof can be placed on the defendant for the affirmative defense. Although the Court has not addressed the constitutionality of defenses per se, the Court has accepted, if not expected, states to provide defenses:

[T] he appropriate use of affirmative defenses enlarges the ameliorative aspects of a statutory scheme for the punishment of crime, rather than the other way around - a shift from primitive mechanical classifications based on the bare antisocial act and its consequences, rather than on the nature of the offender and the conditions which produce some degree of excuse for his conduct, the mark of an advanced criminology.

In Kansas, the burden of proof established for affirmative defenses further supports the conclusion that self-defense is a jury question. When the defendant asserts an affirmative defense, the burden remains on the State to prove every element of the crime charged beyond a reasonable doubt. ${ }^{268}$ Evidence presented by the defendant in support of an affirmative defense is to be considered by the jury in making its determination of whether the State has met its burden. ${ }^{269}$ Because selfdefense generally requires admission of the acts that constitute the crime, if a jury finds the defendant appropriately used force in self-defense, then the defendant's action is justified and she is acquitted.

While not exactly on point, another line of recent United States Supreme Court cases has explored and reaffirmed the primacy of the jury in making determinations of culpability, since culpability is historically directly related to the resultant punishment. These cases relate to

266. See, e.g., Martin v. Ohio, 480 U.S. 228, 236 (1987); Patterson v. New York, 432 U.S. 197, 210 (1977); Mullaney v. Wilbur, 421 U.S. 684, 703 (1975).

267. Patterson, 432 U.S. at 212 n.13 (quoting People v. Patterson, 347 N.E.2d 898, 909-10 (N.Y. 1976)).

268. PIK CRIM. 3d $\S 52.08$.

269. Id. 
sentencing issues, the opposite end of the criminal adjudication from charging decisions that are implicated by K.S.A. 21-3219 and Kirkpatrick. In recent years, state and federal sentencing guidelines, determinative, and sentencing factors have divested juries and judges of traditional roles in the criminal justice system. The movement toward "sentencing factors," to be proved by a mere preponderance of the evidence at sentencing, shifted critical issues of what a defendant is guilty of and how much time she should be sentenced to away from the jury and into the hands of the prosecutor. Sentencing factors reduced the burden of proof the prosecutors had to meet to affect the sentence imposed. In Apprendi v. New Jersey, the Court held that "any fact (other than a prior conviction) that increases the maximum penalty for a crime must be charged in an indictment, submitted to a jury, and proven beyond a reasonable doubt." ${ }^{270}$ Historically, all matters relating to criminal liability, and as a result, punishment, were for the jury. ${ }^{271}$ The jury is regarded as having the role of determining culpability by deciding whether the State has met its burden of proving all elements necessary to support a punishment. ${ }^{272}$ By analogy, a defendant should be able to present her evidence of self-defense at trial, to give the jury the opportunity to determine her culpability and to ensure that the State has proved its case beyond a reasonable doubt.

All these cases affirm the jury's primacy in determining all issues relating to culpability and the necessity of the State meeting its burden of proof at trial. Analyzed under these cases, in Kansas, since evidence relating to self-defense relates directly to whether the State has met its burden of proof, it is not unreasonable to conclude that the evidence must be presented to the jury for its evaluation along with all other evidence. Kirkpatrick and K.S.A. 21-3219, if applied as the plain language would permit, undermine the defendant's right to a jury trial, including the right to require the State to prove every element beyond a reasonable doubt and the right to present a defense.

\section{CONCLUSION}

While Kirkpatrick and K.S.A. 21-3219 applied together create troubling fundamental constitutional questions, if followed by the Kansas Courts, they will create a practical bar to the assertion of self-defense in future cases. In the hypothetical presented at the beginning of this

270. 530 U.S. $466,476(2000)$.

271. Id. at $479-80$.

272. Id. at 482-84. 
Article, there were varying accounts of the events surrounding the victim's death. The shooter testified that he felt threatened when the decedent rushed him with a knife. The shooter's story is corroborated by witnesses at the scene. But, the passengers in the car and other witnesses contradict the shooter's evidence. The case at this point appears to be a credibility determination, traditionally left to the jury to resolve. Now, even if the evidence is conflicting on the events surrounding the shooter's discharge of his gun, once the prosecutor has determined to proceed with the charges of felony murder and criminal discharge of a firearm into an occupied vehicle, the defendant no longer has the right to assert self-defense.

Through a single legislative act and a single Kansas Supreme Court decision, Kansas law of self-defense has been altered in ways that undermine its historic importance, its traditional role as a jury question, and its availability as a defense to a person charged with a forcible felony. While the policies behind the defense may have changed over time, Kansas has never rejected self-defense as a viable justification for the use of force. If the defendant produces evidence that would support a finding of self-defense, the determination of whether the force was justified must fall to the jury in its capacity as finder of fact. More importantly, the defendant has a right to have a jury hear the evidence in her defense and to have the jury decide on her culpability. It is these factual determinations that will drive the jury's decision on self-defense. Kansas cannot remove the decision about whether a defendant has a valid defense from the jury and simply vest it in the prosecutor's office without running afoul of fundamental constitutional requirements. Unfortunately, this is exactly what has happened. 